\title{
Development of Energy Sustainability in the Waste Water Treatment Plant at Chennai
}

\author{
A. Mani, R. Venkata krishnaiah, P. Dayakar
}

\begin{abstract}
Anaerobic absorption (AD) is a demonstrated innovation for sewage slop treatment and which permits age of sustainable power source from a similar procedure. Biogas is delivered by anaerobic assimilation of biomass because of the breakdown of fats, proteins and sugars, which comprise the main part of natural issue. Foul sewage includes ordinary and inorganic solids in isolated and suspended structure with 90-99.9\% of water. After treatment, gigantic extent of sludge stays as strong waste.Around 220cum/day liquid slop is being accumulated each day.
\end{abstract}

Key words: Total solids, volatile solids, Biomethanation, Biocomposting, Biogas, Sewage, Sludge, Anaerobic digestion

\section{INTRODUCTION}

Vitality has a noteworthy efficient and political job as a significant asset exchanged around the world. Vitality utilization in the created nations has been pretty much balanced out while in creating nations like India it is expanding at a high rate[1],[3],[5]. The Government is anticipating Biomethanation Technology (BT) as an optional wellspring of vitality by using modern, farming and civil squanders. A lot of cash is being put resources into this course with different ventures under execution and numerous to tail them. Thus the long haul manageability of the innovation should be made a decision to improve bio-degradability or bioactivity of the treated ooze[2],[4],[6].

\section{A Anaerobic digestion}

Anaerobic assimilation (AD) has turned into an undeniably significant mechanical procedure. Advancement is a green development including the period of methane-rich biogas by methods for the regular debasement of commonly open biomass like plant and common solid wastes and wastewaters. Advancement techniques have for quite a while been used to treat and clean sewage slop waste from oxygen devouring wastewater and animal compost, reduce its smell and volume[7],[9], [11], and produce supportive biogas. Biogas in this manner is a unique, endless biofuel that offers

Revised Manuscript Received on July 22, 2019.

Dr A. Mani, Professor, Department of Civil Engineering, Bharath Institute Of Education And Research, Chennai , Tamil Nadu. E-Mail: maniathi57@yahoo.in

Dr R. Venkatakrishnaiah, Associate Professor, Department of Civil Engineering, Bharath Institute Of Education And Research, Chennai, Tamil Nadu. E-Mail: venkatapec@gmail.com

P. Dayakar, Associate Professor, Department of Civil Engineering, Bharath Institute Of Education And Research, Chennai, Tamil Nadu. E-Mail: dayakarpitti@yahoo.co.in the likelihood of superseding oil based commodities in the transportation part and obliging the net ozone hurting substance transmissions involved in natural change. In the meantime, the slime is settled and its dry issue substance is diminished [31],[33].

The advantages of $\mathrm{AD}$ of sewage slime are generally perceived and the innovation is entrenched in numerous nations. Today, a high extent of biogas delivered in $\mathrm{AD}$ plants is from those on city wastewater treatment destinations and there is as yet a colossal potential to abuse around the world. Sewage slime is delivered in wastewater treatment plants (WWTPs) as a component of the water cleaning process (appeared in Figure 1).

The slime contains the particles expelled from the wastewater, which are wealthy in supplements and natural issue, leaving the water clean for its discharge into nature. Developing populace focus' and extending industry, which are progressively very much served by wastewater treatment offices, bring about fast development of sewage muck creation. As significant purchasers and generators of vitality, [8],[10],[12]

WWTPs are one of the various players impacting advancements towards vitality supportability. The weight has been expanded on the regular wellspring of vitality because of proceed with prerequisite of vitality that expanded the significance of inexhaustible and non-ordinary wellspring of vitality. Then again because of consuming of petroleum product odds of Global warming is likewise expanded by which a large portion of the nations pull in towards the significance of non - ordinary wellspring of vitality. Bio-vitality creation dependent on disintegration of ooze material certainly is useful in taking care of the issue of vitality emergency in the house hold of staff/research facility at site and to expel some weight from the regular wellsprings of vitality (Mukharje,2007).

The thickened sludge siphoned to the anaerobic digester. The muck experiences biodegradation within the sight of methanogenic microbes and created biogas comprises of methane. After anaerobic absorption the processed sludge dried in the sludge drying bed and it tends to be utilized as soil conditioner or treating the soil[13],[15],[17].

The present investigation was centered around biogas generation from the sludge siphoned to the Digester day by day for Digestion. The present investigation expects to energize economical and proficient generation, transformation and usage of biogas in city WWTPs. The greatest biogas creation was seen in volume $70 \mathrm{~m} 3 / \mathrm{ML}$ amid summer and least

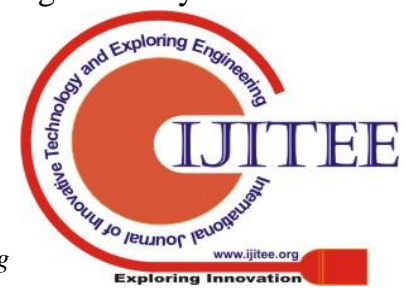


volume of gas creation was seen amid winter as $40 \mathrm{~m} 3 / \mathrm{ML}$ [14],[16], [18].

The biogas is utilized to create vitality source and to work the treatment plant and others as lighting, lab works and so on. The Plant produces power from the biogas delivered in the Sewage Treatment Plant. "The Plant will likewise help in decreasing air contamination by catching and consuming Methane created at Sewage Treatment Plant for power generation",

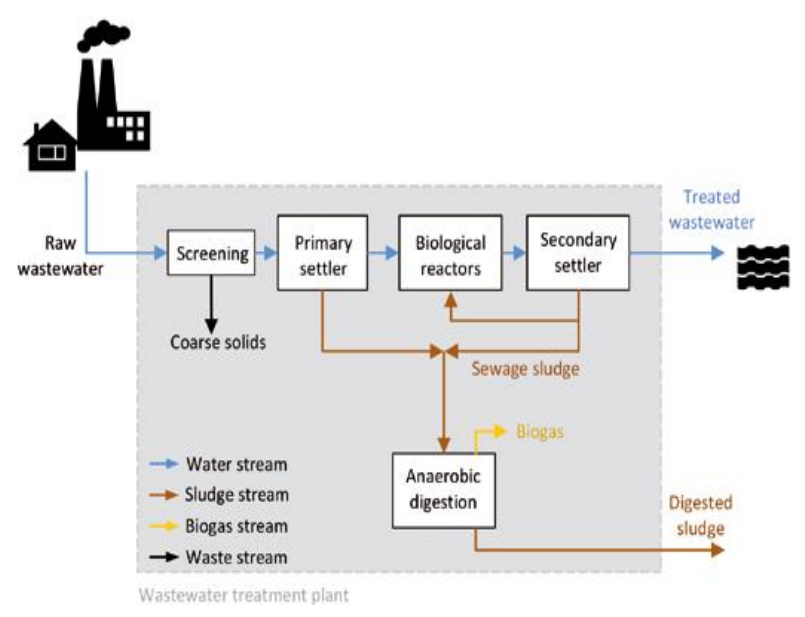

Figure 1- Layout of Waste Water Treatment Plant

\section{RESULTS AND DISCUSSION}

Grungy sewage includes trademark and inorganic solids in split up and Suspended structure with 90-99.9\% of water.Physical qualities of digester ooze were recorded at sewage treatment plant[32],[34],

as $\mathrm{pH}$ was observed most amazing 7.06 in the midst of summer and least 6.89 in the midst of winter, total solids \% was observed most significant in summer $4.20 \%$ and least in winter $3.94 \%$, Volatile solids $\%$ was observed most raised $60 \%$ in the midst of summer and most decreased $57.9 \%$ in the midst of winter in the full scale solids, Alkalinity was most raised 2070 $\mathrm{mg} / \mathrm{l}$ in the midst of summer and most diminished $2050 \mathrm{mg} / \mathrm{l}$ in the midst of winter showed up in the table 1 [19],[21],[23] .

Methanogenic microbes are commit anaerobes whose development rate is by and large slower than the microscopic organisms.

\begin{tabular}{|c|c|}
\hline Total nitrogen & 0.88 percent \\
\hline Total Potassium & 4.98 vecent \\
\hline Total Phosphorous & 2.62 jecent \\
\hline
\end{tabular}

Table 2: Seasonally Biogas production (m3)

\begin{tabular}{|c|c|c|c|}
\hline $\begin{array}{c}\text { Production of } \\
\text { biogas seasonally }\end{array}$ & $\begin{array}{c}\text { Amount of biogas } \\
\text { production }\left(\mathrm{m}^{3}\right)\end{array}$ & Quantity of sludge & $\begin{array}{c}\text { Temperature range } \\
\left({ }^{\circ} \mathrm{C}\right)\end{array}$ \\
\hline Winter & $40 \mathrm{cum} / \mathrm{MLD}$ & $\begin{array}{l}140 \mathrm{cu} \\
\mathrm{m} / \text { day }\end{array}$ & $25-35^{\circ} \mathrm{C}$ \\
\hline & $70 \mathrm{cum} / \mathrm{MLD}$ & $\begin{array}{l}220 \mathrm{cu} \\
\mathrm{m} / \text { day }\end{array}$ & $25-45^{\circ} \mathrm{C}$ \\
\hline
\end{tabular}

Table 3: Seasonally Biogas production (m3)

\begin{tabular}{|c|c|c|c|c|}
\hline Grade & $\begin{array}{c}\% \text { of } \\
\text { replacem } \\
\text { ent }\end{array}$ & $\begin{array}{c}\text { Sample } \\
1\end{array}$ & Sample 2 & $\begin{array}{c}\text { Avg.compressi } \\
\text { ve strength for } \\
7 \text { days } \\
\left(\mathrm{N} / \mathrm{mm}^{2}\right)\end{array}$ \\
\hline & $0 \%$ & 10.10 & 8.35 & 9.225 \\
\hline $\mathrm{M} 20$ & $5 \%$ & 8.65 & 9.35 & 9.00 \\
\hline & $10 \%$ & 7.55 & 9.16 & 8.35 \\
\hline & $15 \%$ & 6.35 & 7.25 & 6.9 \\
\hline
\end{tabular}

Table 4: Chemical characteristics of Digester sludge at STP

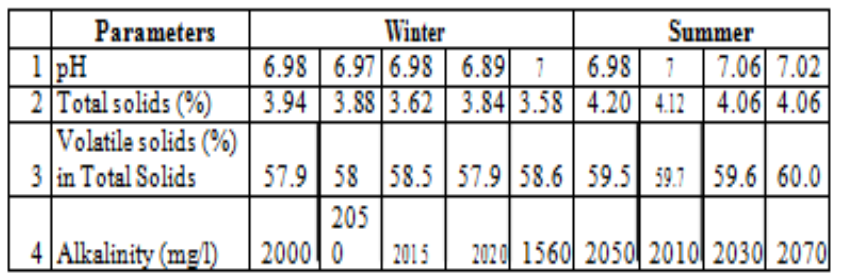

\section{CONCLUSION}

As appeared by Lee et al., (1970) additionally made an examination on bequest scale Biogas plants which have been relied on to process pig slurry of $10 \mathrm{~m} 3$ day - 1 under mesophilic conditions. In this structure, the biogas age rate was $138-\mathrm{m} 3$ day -1 , with $230 \mathrm{~kg}$ of perilous solids movement. To pass on the power, the level of biogas utilized was $1.8 \mathrm{~m} 3$ per $\mathrm{kwh}$ at $5-9 \mathrm{kw}$ power loads. This outcome showed that sensible power source age with 2000 pig was $216000 \mathrm{kwh}$ yr-1 - enough to satisfy the power needs of 100 standard family units in Korea. Chanakya et al. (1992) used colossal piece of SW for biogas age. The anaerobic digester utilized in present examination is having genuine blending. [25],[27],[29]

The compensation to be gotten from sign use in the anaerobic treatment framework is connected with centrality recuperation from the biogas methane made and supplement recuperation from the digester profluent. Biogas containing 73.4 percent methane with calorific respect $6052 \mathrm{k} \mathrm{cal} / \mathrm{kg}$. Hamzawi et al. (1998) assessed the particular legitimacy of the anaerobic co-ingestion of sewage flood with the trademark bit metropolitan strong waste. Utilizing customary progress tests, an ideal blend was related to $25 \%$ standard section of metropolitan strong waste and $75 \%$ sewage reject subject to biogas creation. The city garbage is a high potential bio vitality source and it may be sufficient used for biomethanation process. Results demonstrated that biogas yield of 70 cum/ML, showing the high biodegradability of the feed slop [26],[28],[30].

An examination of biogas yields per ton of feedstock material between dairy animals manure and kitchen waste uncovered that standard sewage squander possibly passes on multiple times more biogas than cow like fecal matter. The biogas made in the 40 MLD

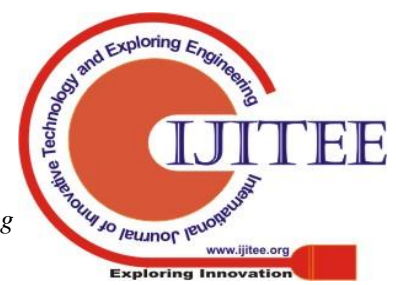


sewage treatment plant is utilized for power age. The power passed on at site is utilized for working the STP and for lighting, and so forth, as such reasonable upkeep of the plant is normally be done and recalling the view to build up the non-standard wellsprings of hugeness.

\section{REFERENCES}

1. Iyappan L., Dayakar P., Identification of landslide prone zone for coonoortalukusing spatial technology, International Journal of Applied Engineering Research,V-9,I-22,PP-5724-5732,Y-2014.

2. Kumar J., Sathish Kumar K., Dayakar P.,Effect of microsilica on high strength concrete, International Journal of Applied Engineering Research,V-9,I-22,PP-5427-5432,Y-2014.

3. Dayakar P., Vijay Ruthrapathi G., Prakesh J., Management of bio-medical waste, International Journal of Applied Engineering Research,V-9,I-22,PP-5518-5526,Y-2014.

4. Swaminathan N., Dayakar P., Resource optimization in construction project, International Journal of Applied Engineering Research,V-9,I-22,PP-5546-5551,Y-2014.

5. Venkat Raman K., Dayakar P., Raju K.V.B.,An experimental study on effect of cone diameters in penetration test on sandy soil, International Journal of Civil Engineering and Technology,V-8,I-8,PP-1581-1588,Y-2017.

6. Saritha B., Chockalingam M.P.,Photodradation of malachite green DYE using TIO2/activated carbon composite,International Journal of Civil Engineering and Technology,V-8,I-8,PP-156-163,Y-2017

7. Shendge R.B., Chockalingam M.P., Saritha B., Ambica A.,Swat modelling for sediment yield: A case study of Ujjani reservoir in Maharashtra, India,International Journal of Civil Engineering and Technology,V-9,I-1,PP-245-252,Y-2018

8. Chockalingam M.P., Balamurgan V.,Modernisation of an existing urban road-sector in Chennai, a case study report,International Journal of Civil Engineering and Technology,V-8,I-8,PP-1457-1467,Y-2017

9. Saritha B., Chockalingam M.P.,Adsorption study on removal of basic dye by modified coconut shell adsorbent, International Journal of Civil Engineering and Technology,V-8,I-8,PP-1370-1374,Y-2017

10. Saritha B., Chockalingam M.P.,Adsorptive removal of heavy metal chromium from aqueous medium using modified natural adsorbent,International Journal of Civil Engineering and Technology,V-8,I-8,PP-1382-1387,Y-2017

11. Chockalingam M.P., Palanivelraja S.,Retrospective analysis of a theoretical model used for forecasting future air quality near the north Chennai thermal power plant,International Journal of Civil Engineering and Technology,V-8,I-8,PP-1457-1467,Y-2017

12. Saritha B., Chockalingam M.P.,Photodegradation of methylene blue dye in aqueous medium by $\mathrm{Fe}-\mathrm{AC} / \mathrm{TiO} 2$ Composite,Nature Environment and Pollution Technology,V-17,I-4,PP-1259-1265,Y-2018

13. Shendge R.B., Chockalingam M.P., Kaviya B., Ambica A.,Estimates of potential evapotranspiration rates by three methods in upper Bhima Basin, In Maharashtra, India,International Journal of Civil Engineering and Technology,V-9,I-2,PP-475-480,Y-2018

14. Shendge R.B., Chockalingam M.P.,The soil and water assessment tool for Ujjani Reservoir,International Journal of Mechanical Engineering and Technology,V-9,I-2,PP-354-359,Y-2018

15. Shendge R.B., Chockalingam M.P.,A review on soil and water assessment tool,International Journal of Mechanical Engineering and Technology,V-9,I-2,PP-347-353,Y-2018

16. Sachithanandam P., Meikandaan T.P., Srividya T.,Steel framed multi storey residential building analysis and design,International Journal of Applied Engineering Research,V-9,I-22,PP-5527-5529,Y-2014

17. Meikandaan T.P., Ramachandra Murthy A.,Study of damaged RC beams repaired by bonding of CFRP laminates,International Journal of Civil Engineering and Technology,V-8,I-2,PP-470-486,Y-2017

18. Meikandaan T.P., Ramachandra Murthy A.,Retrofittng of reinforced concrete beams using GFRP overlays, International Journal of Civil Engineering and Technology,V-8,I-2,PP-423-439,Y-2017

19. Meikandaan T.P., Ramachandra Murthy A.,Flexural behaviour of RC beam wrapped with GFRP sheets,International Journal of Civil Engineering and Technology,V-8,I-2,PP-452-469,Y-2017

20. Meikandaan T.P., Murthy A.R.,Experimental study on strengthening of rc beams using glass Fiber.International Journal of Civil Engineering and Technology,V-9,I-11,PP-959-965,Y-2018
21. Meikandaan T.P., Hemapriya M.,Use of glass FRP sheets as external flexural reinforcement in RCC Beam,International Journal of Civil Engineering and Technology,V-8,I-8,PP-1485-1501,Y-2017

22. Saraswathy R., Saritha B.,Planning of integrated satellite township at Thirumazhisai,International Journal of Applied Engineering Research,V-9,I-22,PP-5558-5560,Y-2014

23. Saritha B., Ilayaraja K., Eqyaabal Z., Geo textiles and geo synthetics for soil reinforcement,International Journal of Applied Engineering Research,V-9,I-22,PP-5533-5536,Y-2014

24. Ambica A., Saritha B., Changring G., Singh N B., Rajen M., Salman Md.,Analysis of groundwater quality in and around Tambaram taluk, Kancheepuram district,International Journal of Civil Engineering and Technology,V-8,I-8,PP-1362-1369,Y-2017

25. Arunya A., Sarayu K., Ramachandra Murthy A., Iyer N.R.,Enhancement of durability properties of bioconcrete incorporated with nano silica,International Journal of Civil Engineering and Technology,V-8,I-8,PP-1388-1394,Y-2017

26. Ilayaraja K., Krishnamurthy R.R., Jayaprakash M., Velmurugan P.M., Muthuraj S.,Characterization of the 26 December 2004 tsunami deposits in Andaman Islands (Bay of Bengal, India),Environmental

Sciences, V-66,I-8,PP-2459-2476,Y-2012

27. Ilayaraja K.,Morphometric parameters of micro watershed in Paravanar sub-basin, Cuddalore District,International Journal of Civil Engineering and Technology,V-8,I-8,PP-1444-1449,Y-2017

28. Ilayaraja K., Singh R.K., Rana N., Chauhan R., Sutradhar N.,Site suitability assessment for residential areas in south Chennai region using remote sensing and GIS techniques,International Journal of Civil Engineering and Technology,V-8,I-8,PP-1468-1475,Y-2017

29. Ilayaraja K., Reza W., Kumar V., Paul S., Chowdhary R.,Estimation of land surface temperature of Chennai metropolitan area using Landsat images,International Journal of Civil Engineering and Technology,V-8,I-8,PP-1450-1456,Y-2017

30. Chitra R.,Experimental study on beam using steel fiber and latex,International Journal of Civil Engineering and Technology,V-8,I-8,PP-1395-1403,Y-2017

31. Chitra R.,Analysis of traffic and management at Kovilambakkam intersection,International Journal of Civil Engineering and Technology,V-8,I-8,PP-1433-1443,Y-2017

32. Aswathy M.,Experimental study on light weight foamed concrete,International Journal of Civil Engineering and Technology,V-8,I-8,PP-1404-1412,Y-2017

33. Aswathy M.,Wastewater treatment using constructed wetland with water lettuce (Eichornia Crasipies),International Journal of Civil Engineering and Technology,V-8,I-8,PP-1413-1421,Y-2017

34. Kiruthiga K., Anandh K.S., Gunasekaran K, Assessment of influencing factors on improving effectiveness and productivity of construction engineers, 2015, International Journal of Applied Engineering Research, V - 10,I -17,p -13849-13854.

\section{AUTHORS PROFILE}

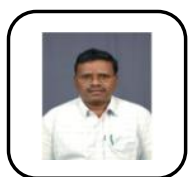

Dr. A. Mani, Professor, Department of Civil Engineering, Bharath Institute of Higher Education and Research, Chennai, India

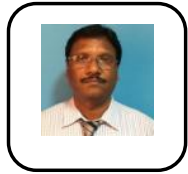

Dr R. Venkatakrishnaiah, Associate Professor, Department of Civil Engineering, Bharath Institute of Higher Education and Research, Chennai, India

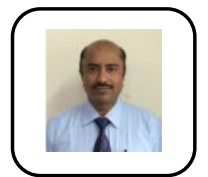

P. Dayakar, Associate Professor, Department of Civil Engineering, Bharath Institute of Higher Education and Research, Chennai, India. 